\title{
APPLICATION OF AN INVERSE DISTANCE WEIGHTED ANISOTROPIC METHOD FOR ROCK QUALITY DESIGNATION DISTRIBUTION IN EASTERN KAHANG DEPOSIT, CENTRAL IRAN
}

\author{
A.B. Yasrebi ${ }^{1 \#}$, A. Hezarkhani ${ }^{1}$, P. Afzal ${ }^{2}$, N. Madani ${ }^{3}$ \\ ${ }^{1}$ Amirkabir University of Technology (Tehran Polytechnic), \\ Department of Mining and Metallurgical Engineering, Tehran, Iran \\ ${ }^{2}$ Islamic Azad University, Department of Mining Engineering, South Tehran branch, Tehran, Iran \\ ${ }^{3}$ Nazarbayev University, School of Mining and Geosciences, Astana, Kazakhstan
}

(Received: September 20, 2018; Accepted: June 17, 2019)

\begin{abstract}
Estimation of Rock Quality Designation (RQD) distribution with low value of error is crucial for mining excavation based on geomechanical data. This paper proposes an application of an Inverse Distance Weighted Anisotropic Method (IDWAM) based on combined variograms to construct $R Q D$ block model in Kahang Copper-Molybdenum (Cu-Mo) porphyry deposit, Central Iran, using subsurface data. To do this, an appropriate voxel size was calculated and then $R Q D$ variography was carried in horizontal and vertical directions. In addition, Deere and Miller rock classification was used to classify RQD block model for a final open pit interpretation. Finally, correlation between results for $R Q D$ estimated derived via the IDWAM and raw data was carried out using jackknife method. The results obtained by the combination of IDWAM and experimental variogram showed that the excellent $R Q D$ zones are located in the central and North Western parts of this area.
\end{abstract}

Key words: Rock Quality Designation (RQD) distribution; Inverse Distance Weighted Anisotropic Method (IDWAM); Combined variograms; Kahang deposit.

\section{Introduction}

Assessment of Rock Quality Designation $(R Q D)$ is a crucial aspect for mineral excavation, resource modelling and mine planning with huge cost implications for the design and the mining of each block such as ore or waste tonnage [1-3]. These are calculated using the dimension and density of each block. The results are assessed to identify a final pit slope angle and consequent pit stripping ratio [4-7]. Numerical models in geosciences have been created and consequently utilised to better interpret the variability of geological parameters such as lithology, ore-type, alteration and mineralogy or for a better understanding of the different attributes such as density, rock mass characterisation and RQD [810]. However, the classical statistical methods for delineation of populations from a background level would be for example, a histogram analysis, box plot, summation of mean and standard deviation coefficients and median. These are not considered overly accurate due to the fact that these statistical methods consider only the frequency distribution of information while not paying attention to the spatial variability $[11,12]$. In other words, the classical statistical plots (i.e., histograms) are based on the data abundance distribution and cannot quantify the spatial positions of parameters such as RQD [13-16]. As a result, numerical modelling of rock characteristics is a difficult task and requires 3D modelling for better interpretation of the problems found in a mining operation such as rock discontinuities, planar failure, circular failure, wedge failure and toppling failure $[17,18]$.

The earliest model regarding the quantitative description of in-situ block size distribution (IBSD) was the Rock Quality Designation, which was

\#Corresponding author: a.b.yasrebi@aut.ac.ir

doi: 10.5937/JMMA1901001Y 
proposed by [19]. Priest and Hudson (1976) applied the RQD method to scanline survey data with respect to an analytical relation between $R Q D$ and the discontinuity frequency resulted from a scanline survey [20]. A borehole or a scanline are by their nature one dimensional. As a result, RQD values calculated using bore hole data or a scanline survey are influenced by the orientation in which the measurements are taken (horizontal or vertical) so the method does not consider calculation for the other direction [21, 22]. In order to overcome the dependence of RQD on orientation, Kazi and Sen (1985) proposed the use of the Volumetric Rock Quality Designation (V. $\mathrm{RQD}$ ) which is a three-dimensional parameter [23]. This encloses the proportion of the volume of intact matrix rock blocks, equal to or higher than 0.001 $\mathrm{m} 3$ in size, which can be associated with the average volume of a matrix block and the number of matrix blocks per $\mathrm{m}^{3}$. To do this, the V.RQD is calculated by summation of the volumes of intact blocks divided by the total rock mass volume which is expressed as a percentage. However, the proposed model is limited to the estimation of the average block volume rather than the IBSD [19, 23]. Palmstrom (1985) proposed different empirical equations to link Volumetric Discontinuity Count for $R Q D$ (known as Jv RQD) data and linear fracture frequency [24]. He suggested that there is a correlation between the in-situ block size and $\mathrm{Jv}$ is represented in a figure incorporating various measurements of the block size or degree of jointing (e.g., density of joints, RQD, block volume and joint spacing). However, this model can only estimate a rough upper and lower range of block sizes and therefore has restricted practical applications [25]. Şen and Eissa (1992) derived values for $\mathrm{Jv}$ for $\mathrm{RQD}$ and block volumes of different shapes such as bars, plates and or prisms quantity [23]. This model which was proposed by Şen and Eissa (1992) provides a simple tool for rock engineers without the need for recourse to theoretical calculations. However, the block volume in this model is given in terms of average block size so it cannot describe the block size distribution [26].
Techniques for selecting a theoretical function to describe rock mass characteristics based on $\mathrm{RQD}$ data are unsatisfactory, as mentioned above. As a result, an approach to introduce an analytical model to help achieve 2D and/or 3D maps for interpreting the distributions of measured RQD is needed. To do this, geostatistical methods can be used for interpolation and estimation of different regional variables (RQD in this scenario). Employment of a proper estimation method regarding geometry and geological properties as well as drilling patterns for different ore deposits is a fundamental issue in resource estimation [27-31]. Linear/ non-linear Kriging methods and Inverse Distance Weighted (IDW) have been widely utilised for block modelling in mineral exploration [32-34]. This paper aims to introduce an application of "Inverse Distance Weighted Anisotropic Method (IDWAM)" to create an RQD block model in Kahang Cu-Mo porphyry deposit, central Iran. The obtained $R Q D$ block model is validated via the Deere and Miller rock classification (Table 1) to suggest an optimised final pit slope.

Table 1. Classification of Rock Quality Designation, Deere and Miller rock classification (1966) [19]

\begin{tabular}{|c|c|}
\hline TERM & RQD \\
\hline very poor & $<25$ \\
\hline poor & $25-50$ \\
\hline fair & $50-75$ \\
\hline good & $75-90$ \\
\hline excellent & $90-100$ \\
\hline
\end{tabular}

\section{Geological setting of the Kahang Cu- Mo porphyry deposit}

The Kahang deposit is located about $73 \mathrm{~km} \mathrm{NE}$ of Isfahan in central Iran. The deposit is situated in the Cenozoic Urumieh-Dokhtar magmatic belt extending from NW to SE Iran, as depicted in Fig. 1 [35-37]. This deposit is mainly composed of Eocene volcanic-pyroclastic rocks, which were intruded by quartzmonzonite, monzogranite to dioritic intrusions in Oligo-Miocene rocks (Fig. 1). The extrusive rocks include tuffs, breccias and 
lavas. The existing lavas in this area have dacitic to andesitic composition. The main criteria aspects for determining detection of mineralised zones are their index ores minerals. Index ores which consist of chalcopyrite and pyrite for hypogene zone, . Furthermore, chalcocite, bornite and covellite for are index minerals for supergene enrichment zone. and malachiteMalachite, azurite, tenorite and cuprite occur for within oxidation zone [38]. Studies Investigation of the pattern of zonation in the eastern part of the Kahang deposit show indicates that the most significant major mineralisation (in terms of ore zone size and geometry) is hypogene zone which containing includes a high percentage volumes of chalcopyrite accompanied byand pyrite. The major main alteration zones of are potassic, phyllic, argillic and propylitic types were accompanied by thewith vein to veinlets fillings of quartz, quartz-magnetite and Fe-hydroxides [3940].
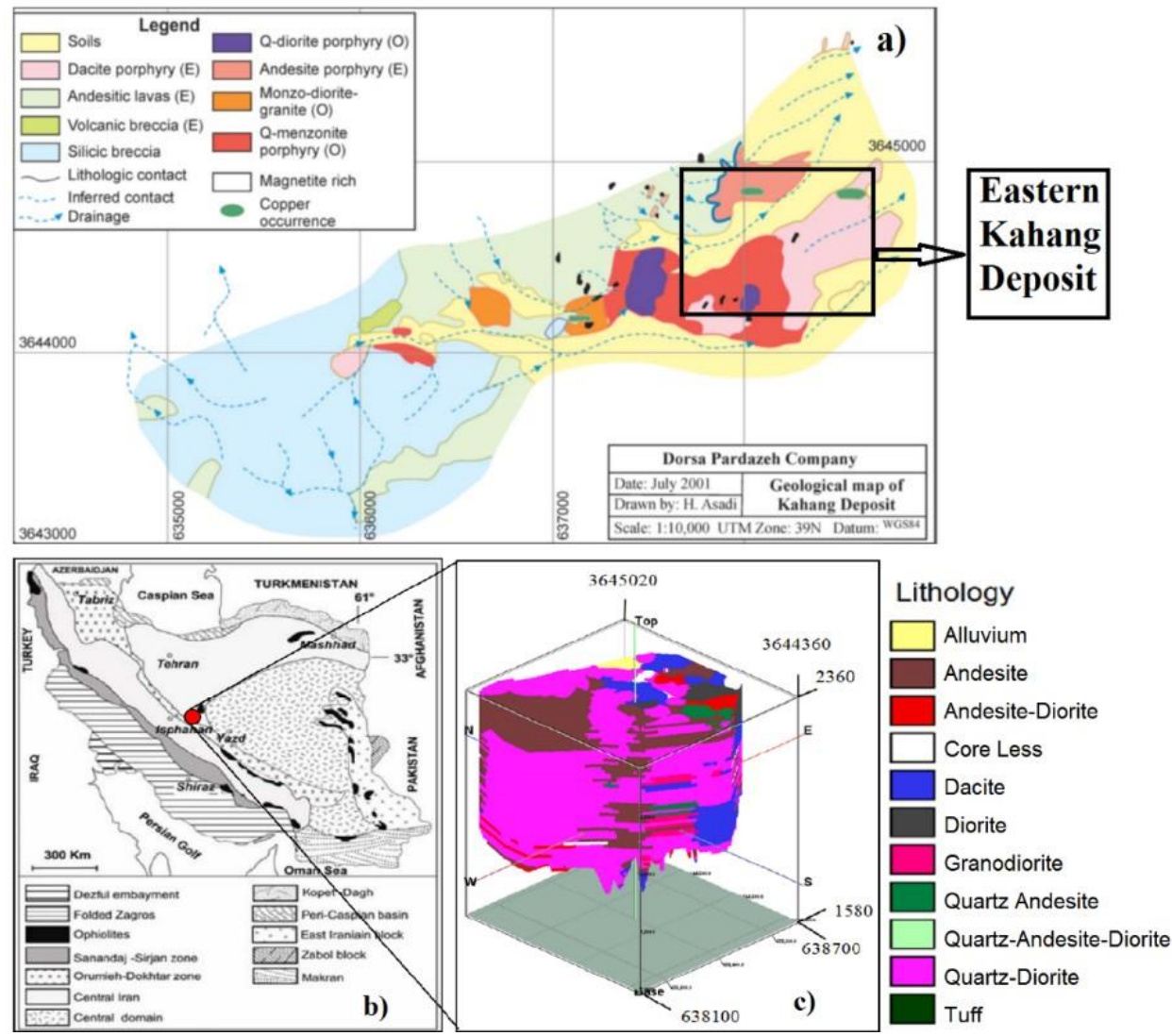

Figure 1. a) Geological map of the Kahang study area, scale: 1:10,000, b) structural map of Iran, showing the Urumieh-Dokhtar volcanic belt [35], and c) 3D lithology model of the Kahang eastern part [41]

\section{Methodology}

In this deposit, 14979 core samples were determined from 42 boreholes with total depth of $\sim 22,000 \mathrm{~m}$ in the deposit for $\mathrm{RQD}$ analysis. Secondly, the subsurface data, including coordinates of drillcores, azimuth and dip (orientation) and RQD values (measured) was generated via RockWorksTM software package. Then, topographical features of the deposit were formed into a 3D geological model (Fig. 2). Finally, geostatistical studies were conducted and subsequently, the IDWAM combined with variography was proposed in order to build the 
$R Q D$ block model based on the dataset (raw data). The final block model was produced by applying an upper and lower filter using RockWorksTM software, based on the topographical surface data (Fig. 2) and borehole data collar heights. Those voxels located above the upper (based on topography) and below the lower and bed rock (based on collar heights) are not considered into the RQD block model construction [3, 42-44]. The Kahang deposit was modelled with 489,927 voxels and each voxel has a dimension of $4 \mathrm{~m} \times 4 \mathrm{~m} \times 10$ $\mathrm{m}$, corresponding the project dimensions of 600 , 660 and $780 \mathrm{~m}$, in the $X, Y$ and $Z$ directions, respectively. This has been done using statistical characteristics of the deposit geometrical particulars consisting of mean, median and median absolute deviation (MAD) [27, 31, 45, 46]. For validation purposes between raw and estimated data, jackknife analysis was utilised.

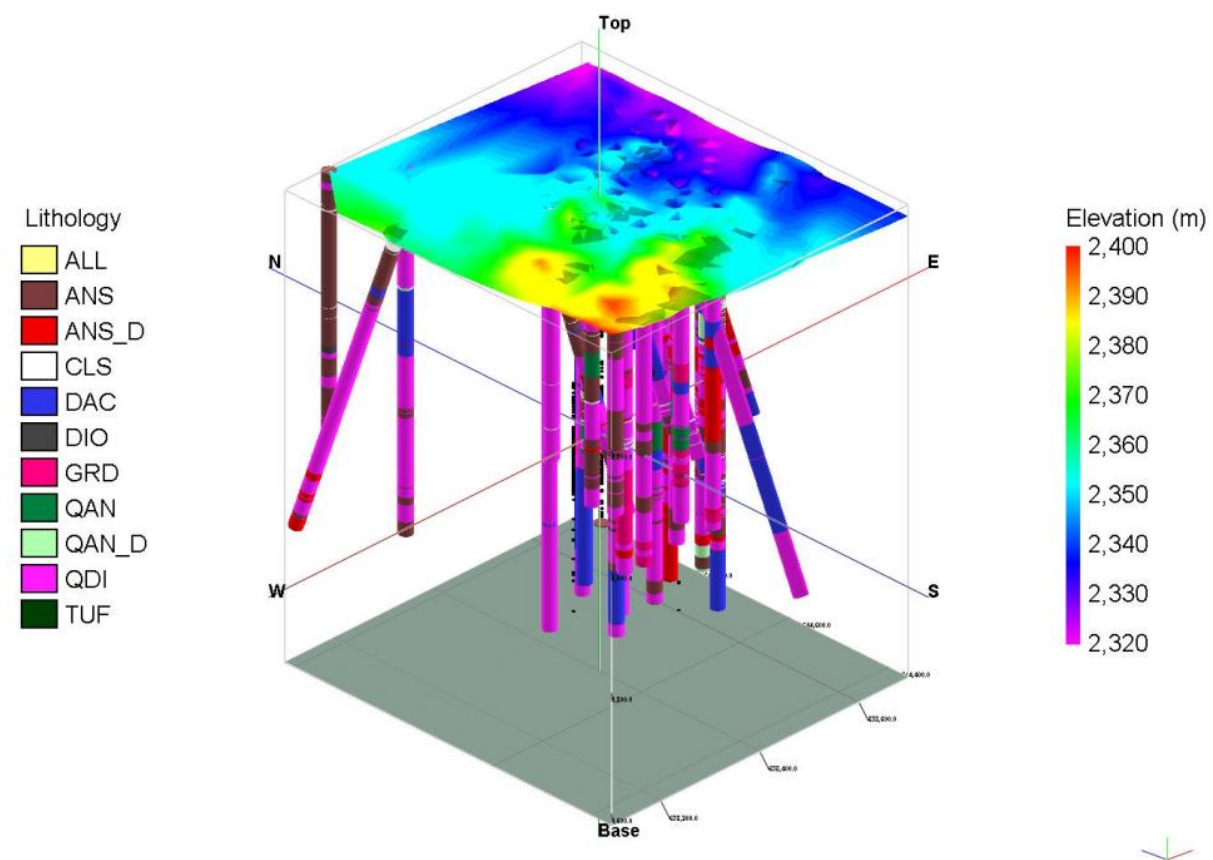

Figure 2. The locations of drill cores with lithological units within the Kahang deposit and its 3D surface topography [31] -Dokhtar volcanic belt [35], and c) 3D lithology model of the Kahang eastern part

3.1. Inverse Distance Weighted Anisotropic Method (IDWAM)

Inverse Distance (ID) is a common gridding and estimation method. Following this, the value assigned to a voxel is a weighted average of either all of the data points or a number of directionally distributed neighbours. The value of each of the data points is weighted with respect to the inverse of its distance from the voxel [17, 30, 31].

Inverse Distance Weighted Anisotropic method (IDWAM) is an interpolation of scattered points
(RQD samples in this scenario) that estimates voxel values by averaging the values of sample data points in the neighbourhood of each processing voxel. IDWAM has a critical assumption that the interpolating surface is mostly influenced by the nearby points and less by the more distant points. The interpolating surface is a weighted average of the scatter points and the weight assigned to each scatter point diminishes as the distance from the interpolated point to the scattered point increases. The main advantage of the IDWAM is to produce a smooth and continuous 
grid and does not exaggerate extrapolations beyond the given data points [32]. Therefore, the IDWAM is recommended for geochemical mapping where the data boundaries (RQD populations) are critical for threshold-based target separation [19]. The range of RQD values will be smaller than the raw data range meaning that highest $R Q D$ values will be less than the maximum of raw data, and the lowest grade values will be greater than the minimum data point [47]. A general form of finding an interpolated value $u$ at a given point $x$ based on samples $u_{i}=u\left(x_{i}\right)$ for $i=1,2, \ldots, N$ using IDW is an interpolating function:

$u(x)= \begin{cases}\sum_{i=1}^{N} \omega_{i}(x) u_{i}, & \text { if } d\left(x, x_{i}\right) \neq 0 \text { for all } i \\ \sum_{i=1}^{N} \omega_{i}(x) & \\ u_{i}, & \text { if } d\left(x, x_{i}\right)=0 \text { for some } i\end{cases}$

where

$\omega_{i}(x)=\frac{1}{d\left(x, x_{i}\right)^{p}}$

$x$ denotes an interpolated (arbitrary) point, $x i$ is an interpolating (known) point, $d$ is a given distance (metric operator) from the known point $x i$ to the unknown point $\mathrm{x}, \mathrm{N}$ is the total number of known points used in interpolation and $p$ is a positive real number, called the power parameter (e.g., an exponent of "2" = Inverse Distance Squared, "3" = Inverse Distance Cubed). The greater the value of the exponent, the less influence distant control points will have on the assignment of the voxel value.

The disadvantages of conventional IDW methods are choice of weighting function which may introduce ambiguity especially where a fixed search radius requires a neighbourhood distance and a minimum or maximum number of points.

\section{Statistical characteristics}

Figure for the original data sets used for RQD values has been generated using MATLAB software, as depicted in Fig. 3. In this deposit, 14979 RQD samples have been measured from 42 boreholes carried out in the deposit (Fig. 3). RQD histogram provides a means for quickly evaluating the range of density and $R Q D$ values for a selected data set without creating a 3D solid model in order to illustrate the highest, lowest, sum, or average data values $[6,9,31]$. These histograms are used to read a single column of data (RQD or density) from a data set to determine the frequency or percentage of the total number of measurements for that variable/attribute that falls within each userdefined grouping. The RQD histogram is not normally distributed which follows a bimodal distribution, with average of $48 \%$ (Fig. 4).

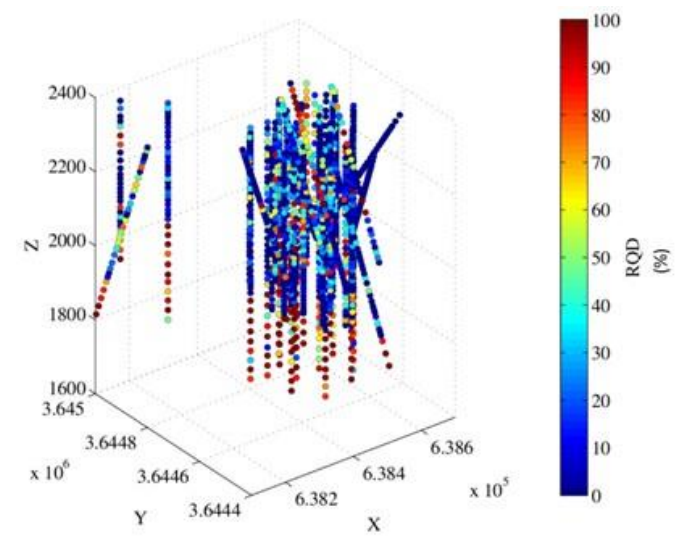

Figure 3. 3D maps for $R Q D(\%)$ original dataset

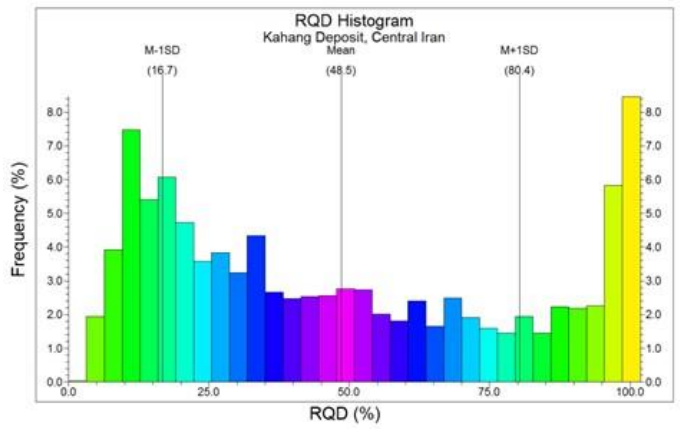

Figure 4. RQD histogram based on raw data for the Kahang porphyry deposit

As a result, there are two main populations with values of $<25 \%$ and $>90 \%$ for $R Q D$ which illustrate that there are two classifications of rock qualities (poor and excellent) with respect to the Deere and Miller RQD classification (Table 1). In addition, with respect to the RQD histogram, the greatest 
frequency of the RQD data corresponds to the excellent rocks within the deposit which will result in the highest stability of the final pit slope.

\section{Block modelling}

Selecting an accurate voxel size for a reserve/resource block model is important for minimising errors $[30,47]$. This issue has been investigated for estimated block model utilising various geostatistical methods such as ordinary kriging (OK) and IDW. Results achieved by the estimation methods are associated with the identification of voxel size in block modelling [27, 48]. Utilising a larger voxel size will maximise the averaging effect in the estimated block model in terms of concentrations. Additionally, a smaller voxel size will show more details, but potentially more error in an anisotropic environment [31, 49]. Furthermore, huge voxel size in the block model changes the higher or lower RQD values of RQD block model by smoothing of these points with high or low values within a large voxel. As a result, it is important to allocate an optimal voxel size considering the deposit geometry and drilling pattern (Figs 2 and 3) [50-53]. David (1970) proposed an applicable method for an operation based on geometrical particulars for different ore deposits and grid drilling [27]. Accordingly, voxel dimensions are determined as follows:

Length and width of each voxel is equal to between half and quarter of the distance between the drill cores according to along the least variability deposit.

Height of each voxel is delineated due to the type of the deposit. In 'massive' deposits such as magmatic deposits (e.g., porphyry deposits), the parameter is equal to the height of excavating benches in the open pit mines [3, 31].

The 2D map of 42 boreholes drilled in the Kahang deposit was constructed by RockWorks ${ }^{\mathrm{TM}}$ v.15 software (Fig. 5). As can be seen, the grid drilling pattern within this deposit is not homogeneous and systematic [17]. As a result, the Kahang deposit was modelled with 489,927 voxels; each voxel having a dimension of $4 \times 4 \times 10 \mathrm{~m}$ in the
$X, Y$ and $Z$ directions based on the geometrical properties of the deposit and grid drilling dimensions [27]. The RQD 3D model is evaluated by IDWAM, which can improve the interpolation of voxel values (RQDs) that lie between data point clusters and can be useful for modelling drill-hole based data in different types of deposit [51].

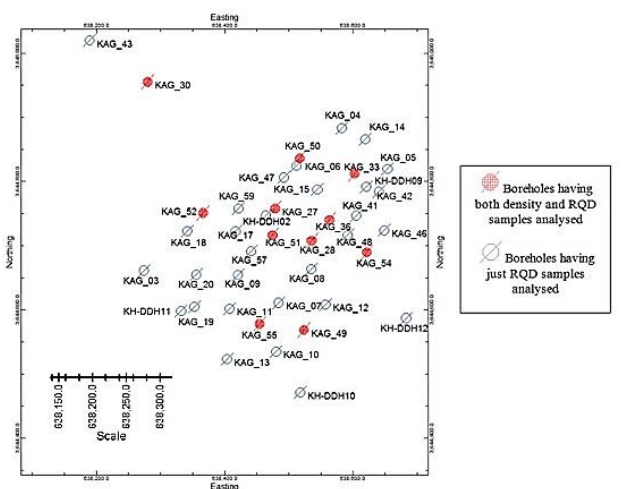

Figure 5. Location of boreholes sampled for density and $\mathrm{RQD}$

Directional and non-directional searching in this method can improve the interpolation of voxel values that lie between data point clusters and be useful for modelling drill-hole based data in the stratiform and massive ore deposits. In this paper, a combination of IDWAM and variography has been used in order to generate a block model in terms of $R Q D$ values based on the following criteria:

1- The grid drilling pattern is irregular and nonsystematic (Figs 2, 3 and 5), with an especially high drilling density in the NE part of the deposit, and low density in the NW part (e.g., two isolated boreholes, as depicted in Fig. 5). Moreover, the grid drilling pattern has an anisotropic geometrical shape.

2- There are too many scattered drill holes in the marginal parts of the deposit which leads to a lack of data.

3- Trends of $R Q D$ values in $X, Y$ and $Z$ show that there is no association between ore grade and $X-Y$ location or depth within the deposit (Fig. 6), indicating again that "Universal Kriging" is not appropriate for this deposit. 


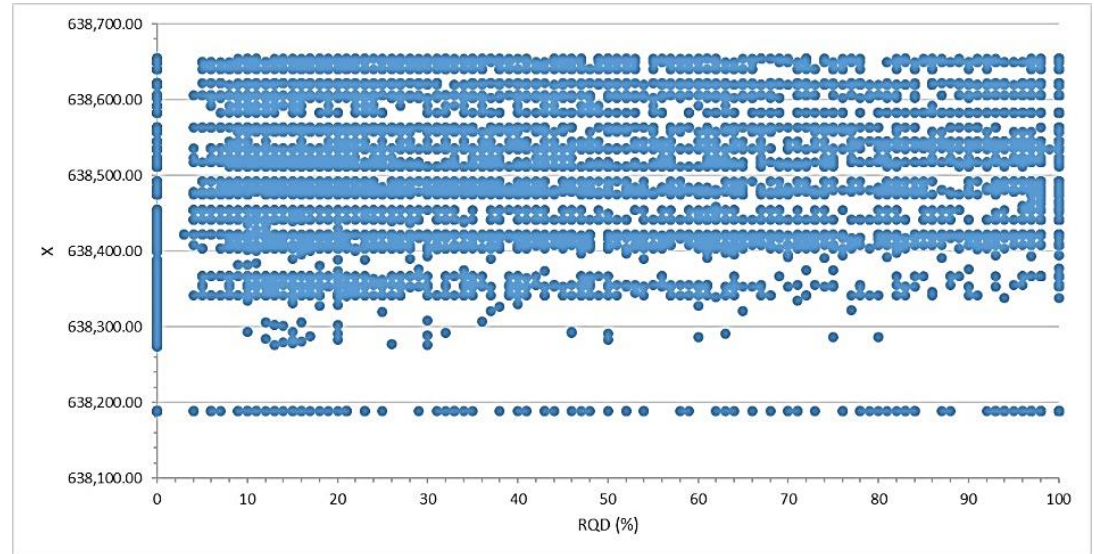

(a)

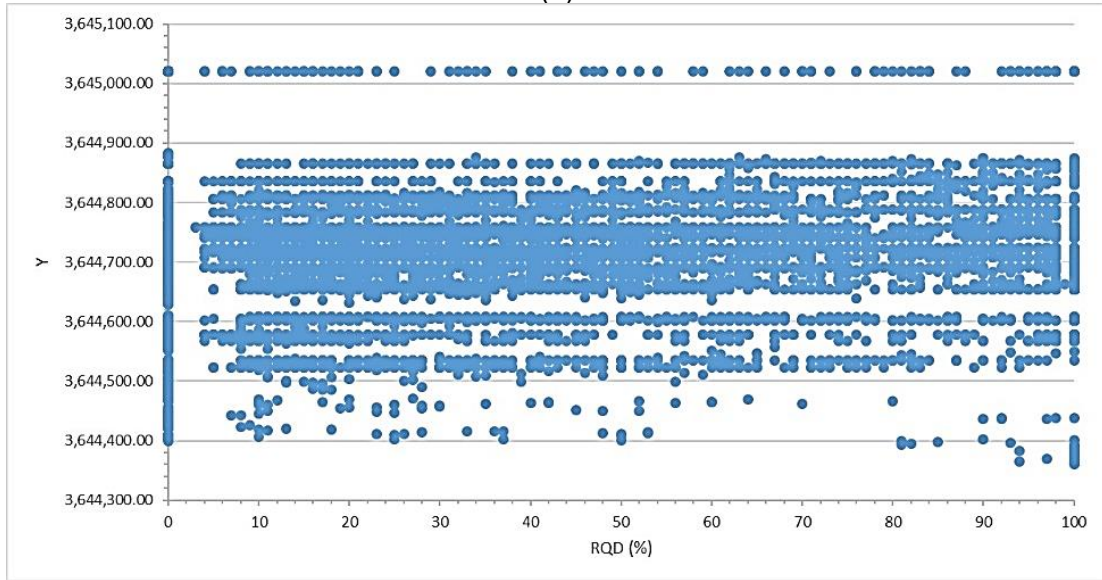

(b)

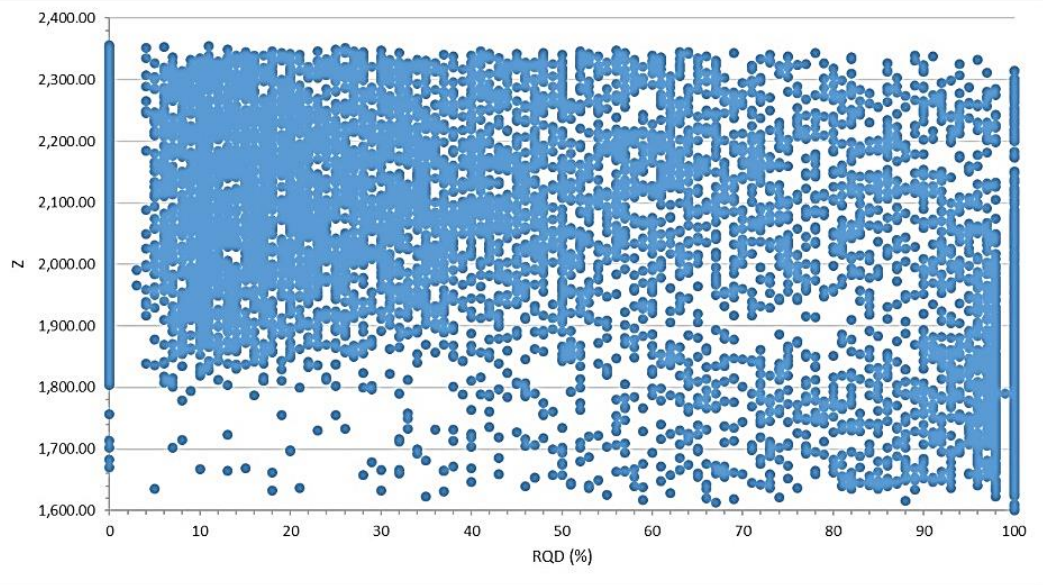

(c)

Figure 6. Scatter plots for correlation between RQD (\%) and coordinates: (a) RQD values trend in $\mathrm{X}$; (b) RQD values trend in $\mathrm{Y}$ and (c) RQD values trend in $\mathrm{Z}$ 


\section{Application of IDWAM}

For $R Q D$, an experimental variogram in horizontal (with lag spacing of $15 \mathrm{~m}$ ) and vertical (with lag spacing of $8 \mathrm{~m}$ ) orientations was produced via MATLAB software with respect to log transformation of $R Q D$ values (raw data), as shown in Fig. 7. From this, the horizontal (Azimuth: 0 and Dip: 0) and vertical (Azimuth: 0 and Dip: -90) ranges for $R Q D$ are $120 \mathrm{~m}$ and $270 \mathrm{~m}$, respectively. The theoretical variogram for $R Q D$ is as follow:

$$
\begin{aligned}
\gamma_{R Q D}(h)= & 135.71+190 \operatorname{sph}(20,20,20) \\
& +499.88 \operatorname{sph}(120,120,270)
\end{aligned}
$$

3D block model for $R Q D$ was generated by IDWAW using the RockWorksTM software package (Fig. 8). The horizontal and vertical ranges of RQD, $120 \mathrm{~m}$ and $270 \mathrm{~m}$, respectively with respect to Equation 3 based on the conducted variograms (Fig. 7), were imported into the horizontal and vertical distance cut-offs in the "Solid Modelling Options" of the software. In order to achieve this, the following tasks in their relative order were carried out:

The Weighting Exponent value was determined as being equal to 2 in order to prompt to enter a real number value for the Inverse-Distance exponent. Number of neighbouring points were defined between 3 and 15 data points that were to be used when computing the voxel value. The horizontal and vertical ranges (known as 'Cut-offs Distances' in the RockWorksTM software) were recognised based on the combined variograms with lags' spacing of $15 \mathrm{~m}$ and $8 \mathrm{~m}$ for horizontal and vertical directions (Fig. 7 and Equation 3 with respect to the theoretical variograms). Following this, 3D block model for RQD was generated by IDWAM, as depicted in Fig. 8.

According to $R Q D$ block model in Kahang porphyry deposit, the $R Q D$ value for excellent rocks $(R Q D>90)$ is situated in the central and NW parts of the deposit. Voxels including good $(75<$ $R Q D<90)$ and fair $(50<R Q D<75)$ rocks are located in the central, eastern and NW parts of the deposit according to the RQD block model and classification of Rock Quality Designation, Deere and Miller rock classification (1966) [19] (Fig. 8 and Table 1).

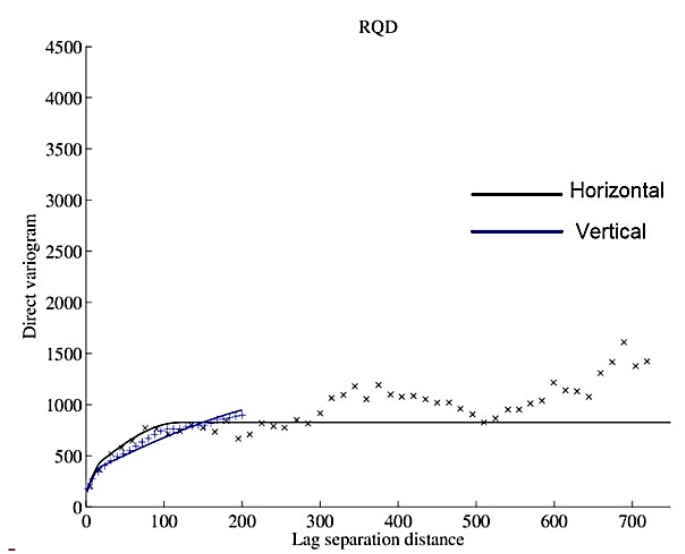

Figure 7. Experimental and theoretical variogram for $\mathrm{RQD}$

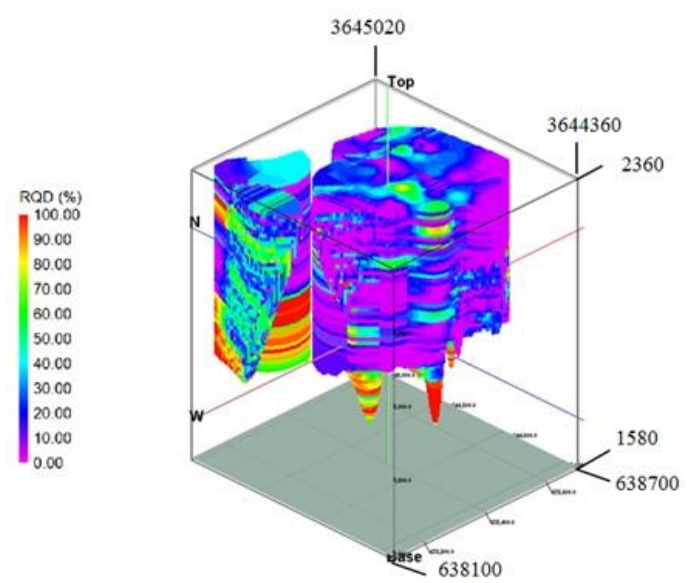

Figure 8. RQD block model in Kahang porphyry deposit determined using estimated data

\section{RQD Spatial Distribution Models with Reliance on Deere and Miller Classification}

The RQD block model (Fig. 8) is delineated to 5 populations with respect to Deere and Miller rock classification (1966; Table 1) for better understanding of $R Q D$ spatial distribution within the generated block model. To do this, the RQD block 
model was distinguished using a mathematical filter facility within the RockWorksTM software which is called "Boolean data type". As a result, the studied 3D model (Fig. 8) was allocated with binary codes (zero or one). Consequently, allocated

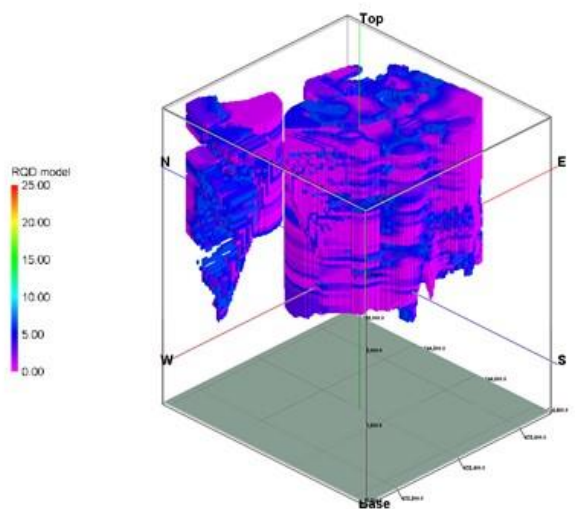

(a)

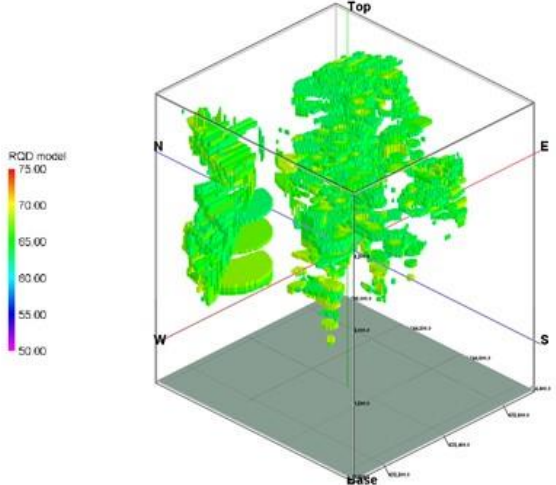

(c) zones (voxels) with $R Q D$ values with the code number of zero are removed and the zones with the code number of one will remain and appeared in the 3D models (Fig. 9).

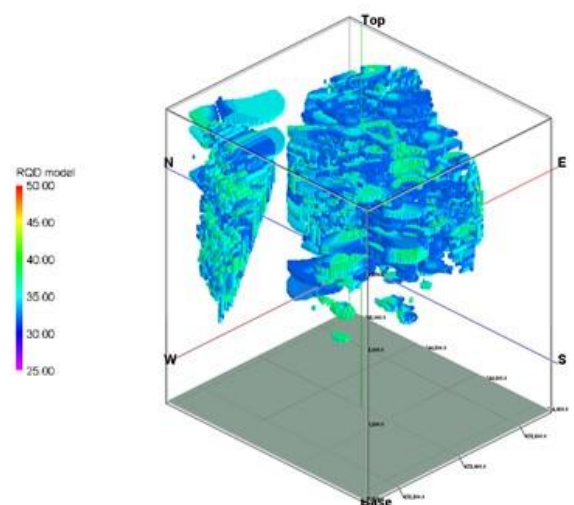

(b)

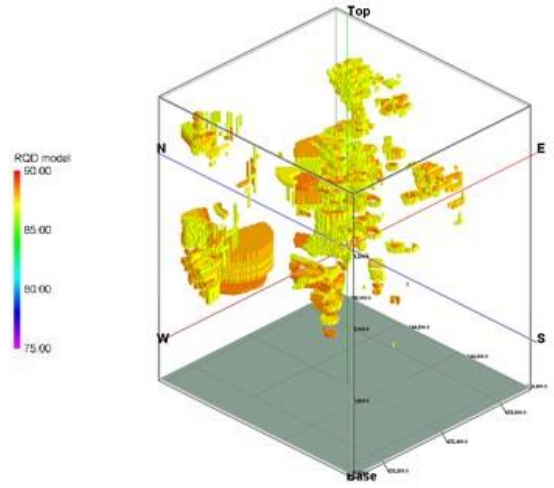

(d)

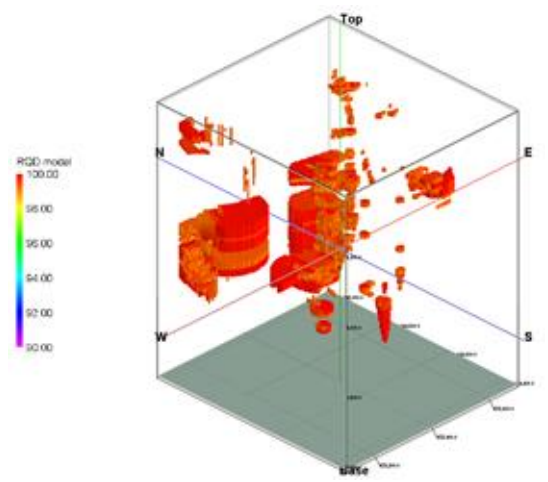

(e)

Figure 9. RQD populations within the Kahang deposit based on thresholds defined from Deere and Miller rock classification: a) very poor zones, b) poor zones, c) fair zones, d) good zones and e) excellent zones 
Based on the Fig. 9a, the majority of the deposit consists of very poor zones which is scattered within the Kahang deposit. As can be seen from Fig. 9b, poor zones are distributed within the most parts of Kahang deposit especially in the NE part. The fair and good zones with $R Q D$ values of 50-75 and 75-90, respectively, are present along NE-NW trend, as depicted in Figs $9 c$ and $9 d$. Excellent zones in terms of RQD occur in the central and NW parts of the deposit (Fig. 9e).

\section{Validation Processes}

There are so many interdependent subjective decisions in a geostatistical study that it is a good practice to validate the results obtained by the estimation method (IDWAM in this scenario) prior to any production run. The generated block model is validated by re-estimating known values under implementation conditions, including the variogram model, estimation method and search strategy, as close as possible to those of the forthcoming production run [53-55]. For validation propose of the estimation, jackknife was used. The term jackknife applies to resampling without replacement, i.e., when alternative sets of data values are re-estimated from other non-overlapping data sets. The jackknife analysis in the Kahang deposit indicates that the correlation coefficient between original data and $R Q D$ estimated is +0.78 , as shown in Fig. 10. In this figure, the diagonal of the square plot (black line) and the linear regression (blue line) was derived and calculated using RockWorksTM program. The jackknife analysis in the Kahang deposit for RQD data indicates that the correlation between original data and estimated $R Q D$ via IDWAM is over +0.7. In this figure, the diagonal of the square plot (black line) and the linear regression (blue line) has a small angle and difference. However, there are some numbers of unexplained variances.

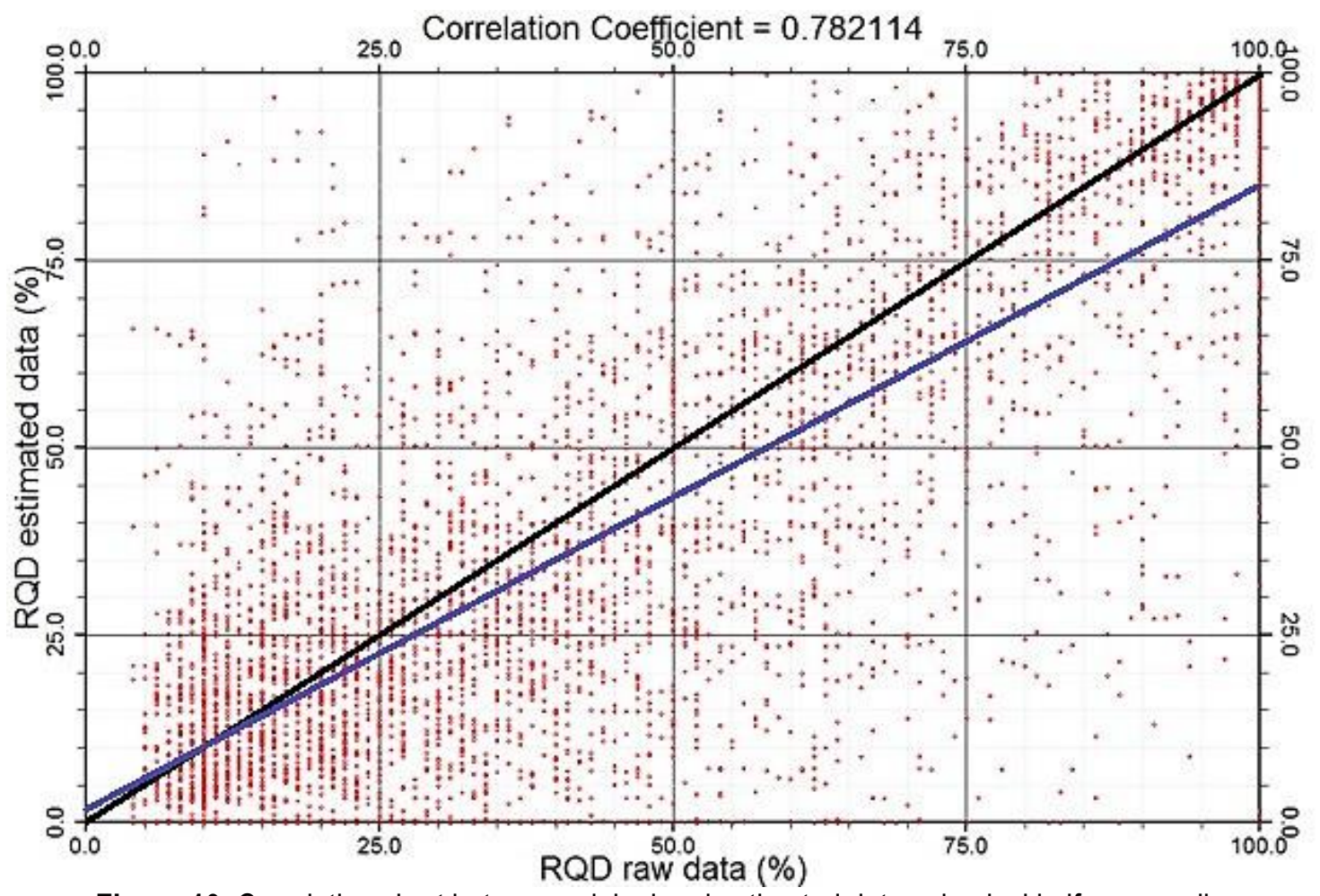

Figure 10. Correlation chart between original and estimated data using jackknife resampling 


\section{Conclusions}

Results achieved by the proposed IDWAM estimation with combined variogram indicated a good correlation equal to $78 \%$ between RQD estimated and raw data. Therefore, it may be resulted that the proposed method can be applied for interpolation of geomechanical data in different types of ore deposits while dealing with nonuniform grid drilling like what it is in Kahang deposit. The RQD block model obtained by the proposed estimator illustrate that the excellent zones considering RQDs higher than $90 \%$ occur in the central and NW parts of the deposit. In addition, the good zones with RQD values between $75-90 \%$ are present in the central, NE and NW parts of the studied area. It is believed that a final pit slope geometry and ultimate pit limit depend on the geomechanical properties such as RQD. However, an awareness of the spatial variability of parameters such as RQD can be used to investigate geotechnical characteristics. This can then be utilised to assess potential slope stability and be incorporated into a geotechnical risk model for the final pit geometry. Regions of high $R Q D$ may be targeted as offering greater potential for increased slope angles or locations for siting of critical haul roads. Regions of lower RQD should, be avoided for final pit limits. From a slope stability point of view, it may be expected that anyone examining RQD block model would consider at least multiple domains for slope stability assessments. However, this is highly recommended that more geotechnical characterisations are necessary to be examined for any potential influence of the 3D fracture network and any major discontinuity-controlled instability.

\section{Acknowledgements}

The authors are thankful to the National Iranian Copper Industries Co. (NIClCO) for their permission to have access to the Kahang deposit dataset. Additionally, the authors would like to acknowledge Mr. Reza Esfahani Pour, manager of Kahang deposit, for his support. The authors also hugely appreciate the Institute of Materials, Minerals and Mining (IOM3) and Iran's National Elites Foundation (INEF) for their financial support in order to conduct this research.

\section{Reference list}

[1] Grenon, M., Hadjigeorgiou, J., (2010). Integrated structural stability analysis for preliminary open pit design. International Journal of Rock Mechanics and Mining Sciences 47, 450-460.

[2] Hamdi, E., Mouza, J.D., (2005). A methodology for rock mass characterisation and classification to improve blast results. International Journal of Rock Mechanics and Mining Sciences 42, 177-94.

[3] Hustrulid, W., Kuchta, M., (2006). Open Pit Mine Planning and Design. Taylor \& Francis.

[4] Lerch, H., Grossmann, I.F., (1965). Optimum design of open-pit mines. Canadian Institute of Mining and Metallurgy 58, 47-54.

[5] Little, M., (2006). The benefit to open pit rock slope design of geotechnical databases. International symposium on stability of rock slopes in open pit mining and civil engineering. SAIMM.

[6] Yasrebi, A.B., Wetherelt, A., Foster, P., Coggan, J., Afzal, P., Agterberg, F., Kaveh Ahangaran, D., (2014). Application of a density-volume fractal model for rock characterisation of the Kahang porphyry deposit. International Journal of Rock Mechanics and Mining Sciences 66, 188-193.

[7] Yasrebi, A.B., Hezarkhani, A., Afzal, P., (2017). Application of Present Value-Volume (PV-V) and NPV-Cumulative Total Ore (NPVCTO) fractal modelling for mining strategy selection. Resources Policy 53, 384-393.

[8] Jinga, L., Hudson, J.A., (2002). Numerical methods in rock mechanics. International Journal of Rock Mechanics and Mining Sciences 39, 409-427.

[9] Rafiee, A., Vinches, M., (2008). Application of geostatistical characteristics of rock mass fracture systems in 3D model generation. 
International Journal of Rock Mechanics and Mining Sciences 45, 644-52

[10] Yasrebi, A.B., Wetherelt, A., Foster, P., Afzal, P., Coggan, J., Kaveh Ahangaran, D. (2013). Application of RQD-Number and RQDVolume Multifractal Modeling to delineate rock mass characterisation in Kahang Cu-Mo Porphyry Deposit, Central Iran. Archives of Mining Sciences 58, 1023-1035.

[11] Boadu, F.K., Long, LT. (1994). The fractal character of fracture spacing and $R Q D$. International Journal of Rock Mechanics and Mineral Science- Geomechanics Abstracts 31, 127-134.

[12] Ehlen, J. (2000). Fractal analysis of joint patterns in granite. International Journal of Rock Mechanics and Mining Sciences 37, 909922.

[13] Baecher, G.B., Lanney, N.A., \& Einstein, H.H. (1977). Statistical description of rock properties and samples. 18th US Symposium on Rock Mechanics, Colorado, USA.

[14] Madani Esfahani, N., Asghari, O. (2013). Fault detection in 3D by sequential Gaussian simulation of Rock Quality Designation (RQD), Arabian Journal of Geosciences 6, 3737-3747.

[15] Rouleau, A., Gale, J.E. (1985). Statistical characterisation of fracture system in the Stripa Granite, Sweden. International Journal of Rock Mechanics and Mining SciencesGeomechanics Abstracts 22 (6), 353-367.

[16] Villaescusa, E., Brown, E.T., (1990). Characterising joint spatial correlation using geostatistical methods, in Rock Joints. In Barton \& Stephansson (Eds.), (pp. 115-122). Balkema publisher, Rotterdam.

[17] Yasrebi, A.B. (2014). Determination of an Ultimate Pit Limit Utilising Fractal Modelling to Optimise NPV. Published PhD Thesis, University of Exeter Publisher, Exeter, UK.

[18] Zhang, L., Einstein, H.H., (2000). Estimating the intensity of rock discontinuities. International Journal of Rock Mechanics and Mining Sciences 37, 819-37.
[19] Deere, D.U., Deere, D.W. (1989). Rock Quality Designation (RQD) After Twenty Years. U.S. Army Engineer Waterways Experiment Station Publisher.

[20] Priest, S.D., Hudson, J.A. (1976). Discontinuity spacing in rock. International Journal of Rock Mechanics and Mining Sciences-Geomechanics Abstracts 13, 135148.

[21] Carvalho, J.L., Carter, T.G., Diederichs, M.S., (2007). An approach for prediction of strength and post yield behaviour for rock masses of low intact strength. Rock Mechanics: Meeting Society's Challenges and Demands, 1st Canada-US Rock Mechanics Symposium, Vancouver, Canada.

[22] Slob, S., (2010). Automated Rock Mass Characterisation Using 3-D Terrestrial Laser Scanning. ITC Publisher.

[23] Şen, Z., Eissa, E.A., (1992). Rock quality charts for log-normally distributed block sizes. International Journal of Rock Mechanics and Mining Sciences- Geomechanics Abstracts 29, 1-12.

[24] Palmstrom, A., (1985). Application of the volumetric joint count as a measure of rock mass jointing, in Fundamentals of rock joints. In Stephansson (Ed.), (pp. 103-109). Centek Publisher, Sweden.

[25] Milne, D., (2007). Rock mass classification challenges. Rock Mechanics: Meeting Society's Challenges and Demands, 1st Canada-US Rock Mechanics Symposium, Vancouver, Canada.

[26] Palmstrom, A., (2005). Measurements of and Correlations between Block Size and Rock Quality Designation (RQD). Tunnels and Underground Space Technology 20, 362-377.

[27] David. M. (1970). Geostatistical Ore Reserve Estimation, Amsterdam, Elsevier.

[28] Boisvert, J.B., Ortiz, J.M. Deutsch, C.V., (2008) 'Local recoverable reserves prediction with block LU simulation', International Journal of Mining and Mineral Engineering 1, 3-21. 
[29] Martins, A.C., Nader, B., De Tomi, G., (2011). A novel application of cellular automata for the evaluation and modelling of mineral resources. International Journal of Mining and Mineral Engineering 3, 303-315.

[30] Shahbeik, Sh., Afzal, P., Moarefvand, P., \& Qumarsy, M. (2014). Comparison between ordinary kriging $(\mathrm{OK})$ and inverse distance weighted (IDW) based on estimation error. Case study: Dardevey iron ore deposit, NE Iran. Arabian Journal of Geosciences 7, 3693-3704.

[31] Yasrebi, A.B., Afzal, P., Wetherelt, A., Foster, P., Madani, N., Javadi, A., (2016). Application of an inverse distance weighted anisotropic method (IDWAM) to estimate elemental distribution in Eastern Kahang $\mathrm{Cu}-\mathrm{Mo}$ porphyry deposit, Central Iran. Int. J. Mining and Mineral Engineering 7, 340-362.

[32] Franke, R., (1982). Scattered data interpolation: tests of some methods. Mathematics of Computation 38, 181-200.

[33] Juan, P., Mateu, J., Jordan, M. M., MataixSolera, J., Meléndez-Pastor, I., NavarroPedreño, J., (2011). Geostatistical methods to identify and map spatial variations of soil salinity. Journal of Geochemical Exploration 108, 62-72.

[34] Gerald van den Boogaart, K., \& TolosanaDelgado, R. (2008). Compositions: a unified R package to analyse compositional data. Computers and Geosciences 34, 320-338.

[35] Alavi, M., (1994). Tectonic of Zagros orogenic belt of Iran: new data and interpretations. Tectonophysics 229, 211-238.

[36] Berberian, M., King, G.C.P., (1981). Towards a palaeogeography and tectonic evolution of Iran. Canadian Journal of Earth Sciences 18, 210-265.

[37] Dargahi, S., Arvin, M., Pan, Y., Babaei, A., (2010). Petrogenesis of Post-Collisional Atype granitoid from the Urumieh-Dokhtar magmatic assemblage, Southwestern Kerman, Iran: Constraints on the ArabianEurasian continental collision. Lithos 115, 190-204.
[38] Berger, B., Ayuso, R., Wynn, J., Seal, R. (2008). Preliminary Model of Porphyry Copper Deposits. U.S. Geological Survey Open-File Report 2008, Reston, Virginia, 20-55.

[39] Afzal, P., Fadakar Alghalandis, Y., Moarefvand, P., Rashidnejad Omran, N., Asadi Haroni, H., (2012). Application of power-spectrum-volume fractal method for detecting hypogene, supergene enrichment, leached and barren zones in Kahang $\mathrm{Cu}$ porphyry deposit, Central Iran. Journal of Geochemical Exploration 112, 131-138.

[40] Afzal, P., Harati, H., Fadakar Alghalandis, Y., Yasrebi, A.B. (2013). Application of spectrum-area fractal model to identify of geochemical anomalies based on soil data in Kahang porphyry-type $\mathrm{Cu}$ deposit, Iran. Chemie der Erde - Geochemistry 739 (4), 533-543.

[41] Yasrebi, A.B., Afzal, P., Wetherelt, A., Foster, P., Esfahanipour, R., \& Parvaz, D. (2012). 3D Lithology, Alteration and Zonation Modelling of the Eastern Part of Kahang Cu-Mo-Au Porphyry Deposit in Central Iran. 12th International Multidisciplinary Scientific GeoConference SGEM, Varna, Bulgaria.

[42] Todorov, J., Popov, K., Shanov, S., Boykova, A., (2002). Geological Conditions for a Correct Geostatistical Evaluation: Example from the Elatsite Copper Deposit in Bulgaria. Kluwer Academic Publishers, Rio, Brazil.

[43] Popov, K.P., Ruskov, K.I., Georgiev, G.I., (2003). 3D Geostatistical model of the ore body in Elatsite porphyry copper deposit, Panagyurishte ore region. 50 years University of Mining and Geology "St. Ivan Rilski" Annual 46 (I), Geology and Geophysics, Sofia.

[44] Yasrebi, A.B., Wetherelt, A., Foster, P., Afzal, P., (2011). Determination and analysis of final pit limit of Esfordi phosphate open pit mine. 22th World Mining Congress, Istanbul, Turkey.

[45] Journel, A.G., Huijbregts, Ch.J., (1978). Mining Geostatistics, Virginia, Academic Press.

[46] Yasrebi, A.B., Wetherelt, A., Foster, P., Afzal, P., Kaveh Ahangaran, D., (2015). 
Determination of an optimum voxel size based on statistical methods in the Kahang Cu porphyry deposit, central Iran. Journal of Mining and Metallurgy, Section A: Mining 51A, 21-28.

[47] Asghari, O., Madani Esfahani, N., (2013). A new approach for the geological risk evaluation of coal resources through a geostatistical simulation Case study: Parvadeh III coal deposit. Arabian Journal of Geosciences 6, 957-970.

[48] Soltani Mohammadi, S., Hezarkhan, A., \& Tercan, E. (2012). Optimally Locating Additional Drill Holes in Three Dimensions Using Grade and Simulated Annealing. Journal of Geological Society of India 80, 700-706.

[49] Emery, X., Ortiz, J.M., (2005). Histogram and variogram inference in the multi Gaussian model. Stochastic Environmental Research and Risk Assessment 19, 48-58.

[50] Journel, A., (1993). Geostatistics: roadblocks and challenges, In A. Soares, (Ed.), (pp. 213224). Geostatistics-Troia.

[51] Lima, A., De Vivo, B., Cicchella, D., Cortini,
M., Albanese, S., (2003). Multifractal IDW interpolation and fractal filtering method in environmental studies: an application on regional stream sediments of Italy, Campania region. Applied Geochemistry 18, 53-65.

[52] Homayoon, S.R., Keshavarzi, A., Gazni, R., (2010). JSEA Application of artificial neural network, kriging, and inverse distance weighting models for estimation of scour depth around bridge pier with bed sill. Journal of Software Engineering and Applications 3, 944-964.

[53] Goovaerts, P., (1997). Geostatistics for Natural Resources Evaluation. Oxford University Press, New York.

[54] Tahmasebi, P., Hezarkhani, A., (2010). Application of Adaptive Neuro-Fuzzy Inference System for Grade Estimation; Case Study, Sarcheshmeh Porphyry Copper Deposit, Kerman, Iran. Australian Journal of Basic and Applied Sciences 4, 408-420.

[55] Deutsch, C., Journel, A.G. (1998)., GSLIB: Geostatistical Software Library and User's Guide Second Edition. Oxford University Press, New York. 


\title{
PRIMENA IDWAM METODE NA RQD RASPODELU STENA ZA LEŽIŠTE U ISTOČNOM KAHANGU, CENTRALNI IRAN
}

\author{
A.B. Yasrebi ${ }^{1 \#}$, A. Hezarkhani ${ }^{1}$, P. Afzal ${ }^{2}$, N. Madani ${ }^{3}$ \\ ${ }^{1}$ Amirkabir University of Technology (Tehran Polytechnic), \\ Department of Mining and Metallurgical Engineering, Tehran, Iran \\ ${ }^{2}$ sslamic Azad University, Department of Mining Engineering, South Tehran branch, Tehran, Iran \\ ${ }^{3}$ Nazarbayev University, School of Mining and Geosciences, Astana, Kazakhstan
}

(Primljen: 20. Septembar 2018.; Prihvaćen: 17.Jun 2019.)

\begin{abstract}
Izvod
Procena $R Q D$ raspodele stena sa malom verovatnoćom greške je presudna za eksploataciju rude na osnovu geomehaničkih podataka. U ovom radu je primenjena IDWAM metoda koja se zasniva na kombinovanim variogramima za izradu RQD blok modela za porfirsko ležište bakra i molibdena (Cu-Mo) u Kahangu, Centralni Iran, gde su korišćeni podaci o podzemnom sloju. Prvi korak je bio izračunavanje odgovarajuće veličine voksela, a zatim je izvršena RQD variografska analiza u horizontalnom $i$ vertikalnom pravcu. Pored toga je korišćena i Dirova i Milerova klasifikacija stena za klasifikaciju RQD blok modela pre konačnog prikaza površinskog kopa. Poslednji korak je bio uporedivanje rezultata za RQD model dobijenih na osnovu IDWAM metode $i$ sirovih podataka prilikom kojeg je korišćena jackknife metoda. Rezultati dobijeni kombinacijom IDWAM metode $i$ eksperimentalnog variograma su pokazali da se odlične $R Q D$ zone nalaze u centralnom i severoistočnom delu ove oblasti.
\end{abstract}

Ključne reči: $R Q D$ raspodela; IDWAM metoda; Kombinovani variogrami; Ležište u Kahangu. 